University of Rhode Island

DigitalCommons@URI

\title{
The "Trump" Effect: Political Elite and Support for Free Trade in America
}

Joseph Essig

Ping $\mathrm{Xu}$

University of Rhode Island, pingxu@uri.edu

James C. Garand

Ceren Keser

Follow this and additional works at: https://digitalcommons.uri.edu/psc_facpubs

The University of Rhode Island Faculty have made this article openly available.

Please let us know how Open Access to this research benefits you.

This is a pre-publication author manuscript of the final, published article.

Terms of Use

This article is made available under the terms and conditions applicable towards Open Access

Policy Articles, as set forth in our Terms of Use.

\section{Citation/Publisher Attribution}

Essig, J., Xu, P., Garand, J. C., \& Keser, C. (2021). The "Trump" Effect: Political Elite and Support for Free Trade in America. American Politics Research, 49(3), 328-342. https://doi.org/10.1177/

$1532673 \times 21992124$

Available at: https://doi.org/10.1177/1532673X21992124

This Article is brought to you for free and open access by the Political Science at DigitalCommons@URI. It has been accepted for inclusion in Political Science Faculty Publications by an authorized administrator of DigitalCommons@URI. For more information, please contact digitalcommons@etal.uri.edu. 
The "Trump" Effect: Political Elite and Support for Free Trade in America

\author{
Joseph Essig \\ Department of Political Science \\ University of Rochester \\ Ping Xu \\ Department of Political Science \\ University of Rhode Island \\ Corresponding author contact: pingxu@uri.edu
}

\author{
James C. Garand \\ Department of Political Science \\ Louisiana State University \\ Ceren Keser \\ Department of Political Science \\ Louisiana State University
}

* This paper was published by American Politics Research — Volume 49, Number 3 (May 2021) 


\begin{abstract}
:
While previous literature has offered two broad categories of explanation for individual trade preferences: economic self-interest and non-economic factors, we contend that during times of intensified elite discourse on trade, individuals may follow elite opinions to form their opinions on trade. Utilizing data from the 2016 American National Election Survey, we examine the effect of Trump's protectionist views and rhetoric on public trade opinion. We argue that there was a "Trump effect" on trade attitudes among the mass public in 2016 and this effect went beyond the party line, meaning that Trump supporters, regardless of their partisanship, were more likely to be influenced by his protectionist views and to adopt anti-free trade positions. Moreover, we suggest a conditional effect of political knowledge on the "Trump effect" of trade opinion. Our empirical tests offer strong support for both hypotheses, suggesting a significant "Trump effect" on public trade opinion in 2016.
\end{abstract}

\title{
Keywords:
}

Trade opinion, Trump effect, political knowledge, protectionism, elite discourse and rhetoric 
The costs and benefits of free trade has been long debated among social scientists. Despite the consensus among economists that free trade is mutually beneficial to involved countries through greater production and more efficient resource allocation, open trade also has inevitable negative political consequences. The rapid growth of open trade in the second half of the $20^{\text {th }}$ century, in part, led to losses of manufacturing jobs and deep discontent among citizens in western developed countries (Margalit 2012; Rodrik 1997). Puzzled by the discrepancy between the widely known benefits of free trade and waves of protectionist sentiment among the public, scholars have endeavored to explore the determinants of public opinion on trade, proposing explanations such as economic self-interests, education, nationalism and ethnocentrism, concerns about the social and cultural consequences, partisanship, issue framing, endorsement, and wording of survey questions (Heckscher 1919; Stolper and Samuelson 1941; O’Rourke and Sinnott 2002; Scheve and Slaughter 2001; Herrmann et al. 2001; Kaltenthaler et al. 2004; Hiscox 2006; Medrano and Braun 2012; Mayda and Rodrik, 2005; Balistreri 1997; Mansfield and Mutz 2009; Margalit 2012; Mutz and Kim 2017; Winslett 2016; Dür and Schlipphak 2020). Building upon previous literature, we contend that during times of intensified elite rhetoric on trade and trade policies, individuals may follow elite discourse to form their trade opinions. In this paper, we examine the effect of political elites on public trade opinion in the context of the 2016 presidential election. In 2016, Trump's negative rhetoric toward trade during the presidential race was a national sensation. A significant part of Trump's campaign was based on criticism of current US trade policy and its large trade deficit. We chose the 2016 election year because this election features the first major presidential candidate in recent US history who fiercely attacked free trade; it provides an excellent example of heightened volume of one-sided elite discourse on the issue of trade. We argue that presidential candidate Donald Trump had a 
strong influence on trade attitudes among the mass public, and this effect could go beyond partisanship. Building on the rich literature of political elites' influence on public preferences, we hypothesize that Trump supporters, regardless of their partisanship, were more likely influenced by his protectionist views because of their pre-existing anti-openness predispositions. In addition, the "Trump effect" should be larger among more knowledgeable Trump supporters because they are more likely to acquire political messages on trade and more able to analyze and accept Trump's messages consistent with their anti-openness predispositions.

Utilizing data from the 2016 American National Election Studies (ANES), we find strong support for our hypotheses. Indeed, supporters of Donald Trump are significantly more likely to oppose free trade and support limiting imports from other countries even after controlling for a full range of explanations suggested by previous literature and accounting for the possibility of reciprocal causality. Furthermore, we find evidence of the conditional effect of political knowledge on this "Trump effect:" politically knowledgeable Trump supporters are more likely to be influenced by Trump's protectionist rhetoric. Interestingly, once we consider "Trump support" as an explanation, we see the effect of partisanship disappears; in a robustness check with split samples we find that the "Trump effect" is more salient among Democrats and Independents.

Taken together, these findings suggest that theories on public opinion formation based solely on economic interests or party-driven changes cannot capture the whole story of trade opinion, and that the persuasive power of political elites does not necessarily only operate through a partisan channel. Our findings contribute to the trade opinion literature by demonstrating that trade attitudes can be influenced by political elites, a viewpoint that prior research on trade opinion has not focused much attention on. In addition, the findings reveal the 
possibility that elite persuasion could sometimes play an even more important role in public opinion formation than economic reasoning or even partisanship.

In the remainder of the paper, we first offer a detailed theoretical account on the determinants of trade opinion proposed by previous literature. We then discuss how and why elite rhetoric may influence citizens' attitudes and extend this to the possible influence of Donald Trump's protectionist rhetoric on Americans' trade opinion, and further, discuss how this relationship may be conditional upon political knowledge. In the next section, we introduce our data and empirical methods used to test our hypotheses. In the last two sections, we discuss the statistical results, our findings and their implications for future research.

\section{Determinants of Trade Opinion}

The most well-known existing research on trade opinion attributes a great deal of the variance in trade attitudes to individuals' economic self-interest (Stolper and Samuelson 1941; O'Rourke and Sinnott 2002; Scheve and Slaughter 2001; Balistreri 1997). For example, the Heckscher-Ohlin theory suggests that in skill-abundant countries, free trade will increase the demand for and raise the relative wages of high-skill workers but decrease the demand for and lower the relative prices of low-skill workers. As a result, high-skill workers will likely support free trade but their low-skill counterparts will oppose it (Stolper and Samuelson 1941). Numerous studies have found empirical support for the Heckscher-Olin theory on trade opinion in the US, Canada, Latin America and in a cross-national context (Scheve and Slaughter 2001; Balistreri 1997; Baker 2003; Mayda and Rodrik 2005; O’Rourke and Sinnott 2001).

The later Ricardo-Viner model argues that workers cannot easily move across sectors in the short run, and therefore one's trade opinion is based on how open trade influences the sector that one works in. As a result, individuals working in import-intensive sectors will oppose free trade, 
but individuals working in export-intensive sectors will support free trade (Brock \& Magee 1978; Irwin 1998). The Ricardo-Viner model, also called the specific factors theory, has gained relatively less empirical support. Researchers find that whether or not an individual works in import- or export-intensive sector is at best a weak predictor of one's trade preferences (Scheve and Slaughter 2001; Hays, Erlich, and Peinhardt 2005; Mansfield and Mutz 2009).

More recently, a growing body of literature argues that trade opinion can be also influenced by non-economic factors such as individuals' feelings about out-groups based on ethnocentrism and nationalism, partisanship, as well as concerns over the social and cultural consequences of trade (Mansfield and Mutz 2009; Margalit 2012; Mayda and Rodrik 2005; O’Rourke and Sinnott 2001; Mutz 2017). For instance, by employing data from the National Annenberg Election Survey and a survey conducted by Knowledge Networks, Mansfield and Mutz (2009) find that economic self-interest, whether it be skill-based or sector-based, has little influence on Americans' trade attitudes. Instead, one's educational attainment is a strong predictor of trade opinion, and education is a reflection of one's anxiety from out-group threats based on tendencies toward nationalism, isolationism and ethnocentrism. Those with higher levels of tolerance for out-groups and with more cosmopolitan worldviews will likely support free trade, but those holding ethnocentric, nationalist and isolationist views will likely oppose free trade (Mansfield and Mutz 2009). Likewise, Kaltenthaler et al. (2004) also find education as the most important predictor of individual attitudes toward trade liberalization.

Building upon this stream of research, Margalit (2012) contends that opposition to free trade can be also caused by individuals' concerns over the social and cultural consequences of open trade, such as increased foreign influence, westernization, and the loss of traditional moral codes. 
In her recent book, Guisinger (2017) argues that concerns over trade's impact on communities and the nation as a whole plays an important role in public trade opinion than one's self-interest.

Another group of researchers focused their attention on political predictors of trade attitudes (Kaltenthaler et al. 2004; Mutz 2017; Hiscox 2006; Medrano and Braun 2012; Winslett 2016; Dür and Schlipphak 2020). Among them, some argue for the importance of partisanship in shaping one's trade opinion (Mutz 2017), while others investigate the effects of framing and endorsement (Hiscox 2006; Medrano and Braun 2012) or the relationship between trade opinion and party competition (Winslett 2016). For example, Mutz (2017) ascribed Americans' trade opinion changes after 2016 to party realignment. According to her, even though the Republican party was known as the party of free trade in America for decades, conservatives and Republicans began to show more negative views about free trade compared to their liberal and Democratic counterparts in recent years. The primary reason was because conservatives and Republicans have long held higher levels of nationalist views, racial antipathy and social dominance orientation, all of which could contribute to opposition to open trade (Mutz 2017). Medrano and Braun (2012) argue that the majority of citizens are uninformed and their answers to survey questions on free trade depends on how survey questions are framed, their perceived degree of economic vulnerability and endorsements by political parties and interest groups.

Framing and endorsement are two other political predictors that are found to influence public trade opinion. In an experiment, Hiscox (2006) discovers that participants are $17 \%$ less likely to favor freer trade when exposed to anti-trade framing such as discussions linking trade to job losses; however, pro-trade framing linking trade with lower consumer prices does not have an effect on individuals' trade opinion. Additionally, Hiscox (2006) finds that less educated respondents are more sensitive to the framing effect, and endorsement can raise support for trade 
across the board especially among those who received anti-trade framing. Using a survey experiment, Dür and Schlipphak (2020) only find limited evidence for elite cueing effects on citizens' support for the Transatlantic Trade and Investment Partnership (TTIP) in both Germany and Spain, but they argue that the elite cueing effects are likely understated because of participants' possible exposure to elite cues outside the context of the experiment. Other research on trade opinion suggests that the general public is less likely than elites to support free trade (Hermann et. al, 2001), and that parties do change their approach to trade policy depending on the distribution of public opinion in the electorate (Winslett 2016).

Another type of framing that could affect Americans' trade opinion is the connection of trade issues with China. In an experimental study, Kerner, Sumner and Richter (2020) show participants a pet furniture advertisement mentioning offshore production and then ask their support for free trade. They find that only the "offshore production in China" prime reduces support for free trade. It is not surprising that Americans connect China with their attitudes toward free trade, as it is widely perceived that trade with China has caused higher unemployment, lower labor force participation, and reduced wages in local labor markets in the US (Autor et al. 2013; 2016).

\section{Beyond the Party Line: The Influence of Elite Rhetoric on Trade Opinion}

Even though the trade opinion literature has not focused a lot of attention on the effect of political elites, public opinion scholars have had a long tradition exploring the influence of political elites on citizens' policy preferences in general (Zaller 1992; Jacoby 1988; Cohen 2003; Johnston 2006; Broockman \& Butler 2017, Gabel \& Scheve 2007). In his classic work, Zaller (1992) argues that mass public opinion is influenced heavily by political elites such as politicians, upper-level government officials, journalists, political activists, and policy 
specialists. Zaller uses the "Receive-Accept-Sample" model to explain how political elites can play an important role in individuals' formulation of political opinions. Besides Zaller's research which is perhaps the most well-known work in the field, other scholars have argued for the importance of political elites in changing citizens' opinion on policy issues. For instance, Abramowitz (1978) finds that voters update their issue attitudes after learning about candidates' positions in a presidential debate. In a field experiment, Minozzi et. al (2015) find that political leaders can persuade their constituents' attitudes toward policy issues after interacting with them in online townhalls. Broockman and Butler (2017) also find that elites' positions influence voters' opinion in a field experiment where they send letters to citizens stating their legislators' policy positions. Gabel and Scheve (2007) find that negative elite messages about European integration decreased public support for European Union.

The normative implications of empirical evidence of elite-driven attitudes have drawn some scholarly attention too. For example, Hochschild (2012) raises questions about the meaning of democracy in a world in which mass opinion is driven largely by elite cutes, particularly in light of Zaller's suggestion that elite opinion is better informed and hence has advantages over mass opinion. Hochschild identifies instances in which mass opinion correctly follows elite opinion (e.g., civil rights laws, tobacco smoking), as well as others in which mass opinion correctly deviates elite opinion (e.g., mass resistance to Clinton impeachment, the Tea Party movement). Druckman, Peterson, and Slothuus (2013) explore the effects of polarization on mass susceptibility to elite cues and find that under conditions of high polarization, individuals are much more likely to follow and incorporate into their policy attitudes elite policy cues.

In this paper, we build upon existing research on elite discourse and public opinion and argue that citizens' trade opinion can be influenced by political elites. While the consideration of 
elite influence on public opinion in general is not brand new, our specific focus on the nexus between political elites and public trade opinion contributes to the trade opinion literature. Even though Hiscox (2006) and others have initiated exploration in this area by studying the effects of framing and endorsement on trade opinion, aside from their work, political elites' influence on public trade opinion remains relatively understudied. The effect of political elites on trade opinion is particularly relevant today considering that in recent years, numerous nationalist politicians in Latin America, Europe and the United States have focused on attacking free trade and seeking protectionist policies in their political campaigns, with Trump as a prime example.

\section{How Trump's Protectionist Discourse Influences Trade Opinion}

In 2016, Trump based a significant part of his campaign on criticism of current US trade policy and its large trade deficit. Trump often cited examples of job losses and factory shutdowns in the Rust Belt in the Midwest and Northeast to make his case (see a few examples of his rhetoric in the endnote $)^{1}$. In addition to criticizing domestic trade policies, Donald Trump also blamed the US's trade partners - especially China. Trump persistently asserted that certain trade partners were the culprit of the decline of certain industries in the US, especially manufacturing, and that US was being taken advantage of by its trade partners. For example, calling the U.SChina trade balance a "theft," he said, "we can't continue to allow China to rape our country" (Diamond 2016) (see a few more examples of similar rhetoric in the endnote) $)^{2}$. Trump made particularly effective use of various media strategies to gain exposure and disseminate his messages (Azari 2016). Along with traditional rallies, his protectionist rhetoric was widely disseminated through social media such as Twitter (Wells et al. 2016).

Zaller's "Receive-Accept-Sample" model suggests that individual citizens acquire information from elites or trusted sources, filter it and accept information that comports with 
their own preconceived values; when answering survey questions they will then sample information available at the top of their heads (Zaller 1992). Empirical evidence suggests that when contested issues are given significant media coverage, individuals take notice and update their own policy ideas consistent with their predispositions (Dancey \& Goren, 2010). According to Zaller (1992), political predispositions are shaped by a person's lifetime experiences, such as childhood socialization and policy-related everyday experiences like paying taxes, working, or racial discrimination. Predispositions influence people's responses to elite information by regulating the acceptance or nonacceptance of the political messages received.

In 2016, Trump supporters came from different backgrounds but the core Trump supporters shared a commonality—-they all had pre-existing anti-openness predisposition. Recent research points out that the core Trump supporters in 2016 were either those who are "left behind" (McQuarrie 2017; Hackworth 2019; Clark 2017) or those who felt "status threat" from increased diversity and globalization (Mutz 2018; Major et al. 2016; Knowles and Tropp 2018; Blum and Parker 2019). Both of these two types of Trump supporters already had anti-openness predispositions before Trump even ran for the presidency. For instance, the first type of Trump supporters, those who are left behind economically such as workers in the Rust Belt of the Midwest and Northeast, likely already blamed international trade, openness and outsourcing for their job losses prior to 2016. When hearing Trump talk about unfair trade deals, trade deficits, and the connections with job losses, they will easily connect their own situation with these messages. Similarly, the other group of Trump supporters, i.e., individuals who felt their majority racial status or America's global dominance status being threatened, may already have blamed openness for bringing in immigrants and blamed globalization for America's economic decline. When they hear Trump speak about America losing to other countries, they may quickly 
connect free trade with American's economic decline in the world and consequently form antitrade opinions.

Given that individuals are most likely to take notice of information consistent with their predispositions and use that information to update their own policy ideas, we can safely argue that these two core groups of Trump supporters will be most likely influenced by his protectionist rhetoric in their trade opinion formation process due to their pre-existing antiopenness dispositions. ${ }^{3}$

Even though there is a rich body of literature that focuses on the influence of party identification on public opinion formation ${ }^{4}$, we argue that there are nuances between the effects of political elites and partisanship. Lenz (2012) suggests that individuals often bring their issue attitudes in line with views of their preferred candidate instead of those of their parties. Based on Lenz's foundational work, we contend that the persuasive power of political elites does not solely operate through a partisan channel; instead, the political elite can persuade supporters by tapping into their political predispositions similar to his or hers. Such persuasive power can reinforce one's prior partisanship, but it can also make one challenge his or her prior partisan views. For example, a voter who identified as a Democrat in previous elections finds Trump an attractive candidate because of his stance on immigration policy might also end up adopting his position on trade, even though the voter is cross-pressured by his or her prior party identification. Despite this attitude change, the voter may not necessarily change their party affiliation immediately, given that it is typically stable over time. It is documented that many Democratic voters in the Rust Belt states, for example, chose to support Donald Trump in 2016 without changing their partisanship; many of them continued to vote Democratic in the 2018 midterm election (Cohn \& Miller 2018; Dias et al. 2016). 
Therefore, a simple partisan explanation of mass policy attitudes cannot account for this pattern of change, especially in an era with prominent political figures that do not clearly fit traditional party lines. Given this, it is meaningful to analyze whether individuals' opinions are influenced more by partisanship or by the political elite they choose to follow. Even though Mutz's (2017) recent work on trade opinion ascribed the change of Americans' trade opinion to party realignment, we argue that the effect of political elites might be another important reason for the change and the Trump effect could go beyond partisanship.

Based on these arguments, we propose that core Trump supporters, regardless of their partisanship, tend to have pre-existing anti-trade and anti-openness predispositions; when exposed to Trump's protectionist rhetoric, such pre-existing political predisposition among Trump supporters can be "waken up" and reinforced. Therefore, compared to non-Trump supporters, Trump supporters are more likely influenced by Trump's anti-trade views in forming their trade opinion. This "Trump effect" could go beyond the traditional Democratic-Republican partisan divide. From this, we develop our first hypothesis:

Hypothesis 1: Trump supporters, regardless of their partisanship, are more likely to accept Trump's protectionist rhetoric and form anti-free trade opinions.

\section{Political Knowledge as a Mediator}

A major part of Zaller's intellectual contribution in public opinion lies in the mediating role of political knowledge in accepting political information to form issue attitudes. According to Zaller, individuals with higher levels of political knowledge are more likely to acquire and comprehend ("Receive") political messages concerning a certain political issue, especially complex issues that are less relevant to their own everyday experience. Additionally, when receiving political messages from elites, individuals with higher levels of political knowledge are 
more able to analyze received information, resist arguments contrary to their political predispositions and accept information consistent with their predispositions. Political knowledge therefore plays a dual role in the opinion formation process: on the one hand, it increases the likelihood for one to acquire political information; on the other, it enhances one's ability to analyze and accept political messages consistent with their own political predispositions. Those who possess higher levels of political knowledge are better at both tasks, resulting in a higher chance for them to be influenced by information consistent with their predispositions. Because Trump's supporters are already more likely to hold predispositions against openness, among them, those with higher levels of political knowledge will be more likely to acquire information on trade-related issues and more likely to analyze and accept Trump's anti-trade rhetoric.

More intuitively, if we compare two Trump supporters: Trump supporter A with high levels of political knowledge and Trump supporter B with low levels of political knowledge. Even though both supporters likely have anti-trade predispositions, supporter A is more likely to pay attention to Trump's speech on trade and more likely to search for Trump's trade policy claims. Even more crucially, supporter A's political knowledge will help him/her analyze the messages and absorb the information consistent with his/her own pre-existing anti-openness predisposition. When asked a trade-related survey question, supporter A will more likely sample the accepted information to answer the question. In contrast, supporter B with low levels of political knowledge will be less attentive to political speeches, resulting in less exposure to Trump's protectionist rhetoric. Even when B catches the messages, he/she is less able to analyze and absorb the information to update their own trade opinion.

One may argue that political knowledge can help individuals critically analyze the messages and as a result increase the chance of rejecting Trump's messages. Indeed, according to 
Zaller, those with higher levels of political knowledge are more able to critically analyze the messages they receive, but they will reject the messages inconsistent with their own predispositions instead of messages inconsistent with scientific findings for example. For individuals whose predisposition on trade differs from Trump's views, it is true that high levels of political knowledge will enhance the chance for them to critically analyze and then reject Trump's anti-trade rhetoric. In other words, high-knowledge Trump opposers are least likely to be influenced by Trump's anti-trade rhetoric when shaping their opinion. Based on these arguments, we posit our second hypothesis:

Hypothesis 2: More knowledgeable Trump supporters are more likely to be influenced by Trump's protectionist rhetoric. In contrast, more knowledgeable Trump opposers are least likely to be influenced by Trump's protectionist rhetoric.

\section{Data and Methods}

In order to test our hypotheses, we employ data from the 2016 ANES, and we use two measures of trade opinion: (1) attitudes toward import restrictions and (2) attitudes toward free trade agreements. We use logistic regression and ordinal logistic regression to predict individual trade opinion as a function of Trump support, political knowledge, the interaction of Trump support and political knowledge, as well as a full set of control variables. Detailed descriptive statistics of all variables are included in the Supplemental Material. ${ }^{5}$

\section{Dependent Variables}

Attitudes toward import restrictions. Our first dependent variable is based on the following question: "Some people have suggested placing new limits on foreign imports in order to protect American jobs. Others say that such limits would raise consumer prices and hurt 
American exports. Do you favor or oppose placing new limits on imports?" $62.23 \%$ of respondents favored placing new limits on imports, which is coded as $0.37 .77 \%$ respondents opposed placing new limits on imports, which is coded as 1 .

Attitudes toward free trade agreements. The second dependent variable is based on the question: "How strongly do you favor, or oppose the U.S. making free trade agreements with other countries?" We combine the seven-point scale response into three categories: favor (coded as $2,39.51 \%$ ), neither favor nor oppose (coded as $1,40.29 \%$ ), and oppose (coded as $0,20.2 \%){ }^{6}$

\section{Independent Variables}

Support for Donald Trump. Support for Donald Trump is measured by one's feeling thermometer (0-100) of Donald Trump, with 0 indicating the respondent does not like Trump and 100 meaning (s)he likes him.

Political knowledge. We create an additive score based on nine political knowledge questions. These questions include: whether or not the respondent knows Senate term is 6 years, foreign aid is the smallest federal spending item, Republicans control the House and Senate, and whether the respondent can identify Joe Biden, Paul Ryan, Angela Merkel, Vladimir Putin and John Roberts. These nine items have an alpha statistic of 0.72 .

Support for Trump xpolitical knowledge. In order to capture the conditional effect of political knowledge, we include a multiplicative term of the two variables.

\section{Control Variables}

Skill level. The Heckscher-Ohlin theory argues that in skill-abundant countries like the US, high-skill workers will likely support free trade but their low-skill counterparts will oppose it (Stolper and Samuelson 1941). We include a measurement for individual skill level and utilize 
the proxy of average income by industry and match that with each respondent to indirectly capture skill level following previous research (Mansfield and Mutz 2009). ${ }^{7}$

Import orientation. The Ricardo-Viner model argues that individuals working in importintensive sectors will oppose free trade, but individuals working in export-intensive sectors will support free trade (Brock \& Magee 1978; Irwin 1998). We consider the export orientation and import orientation of one's industry, and calculate them by $\ln \left(\frac{\text { industry exports }}{\text { industry GDP }}\right)$ and $\ln \left(\frac{\text { industry imports }}{\text { industry GDP }}\right) .{ }^{8}$ These two measurements are highly colinear so we only include import orientation in our models.

Partisanship. Considering the important role of partisanship on public opinion, we include one's party identification as a control variable. Partisanship is a 7-point scale indicator, with 7 indicating strong Republican and 0 indicating strong Democrat.

Financial worry. In addition to the objective measures of economic self-interest, we also capture the subjective assessment of one's financial situation as an explanation for trade opinion. We posit that individuals who worry about their financial situation are likely more vulnerable in the open trade environment and therefore may more likely oppose open trade. To measure individuals' perception of their own financial status, we use the following question, "how worried are you about your current financial situation."

Nationalism and Ethnocentrism. A growing body of literature argues that trade opinion can be also influenced by non-economic factors such as ethnocentrism and nationalism (Mansfield and Mutz 2009; Mayda and Rodrik 2005; O’Rourke and Sinnott 2001; Mutz and Kim 2017). To capture nationalism, we consider five questions related to nationalist sentiment, and combine them by using principal component factor analysis and regression scoring. ${ }^{9}$ Feelings toward out-groups, or ethnocentrism, is measured by feeling thermometers of three minority 
groups: Blacks, Hispanics, and Asians (each ranging from 0-100). We use principal component factor analysis in the same way to generate a factor score of ethnocentrism. ${ }^{10}$

Demographic controls. We also include demographic control variables such as age, household income, education, union membership, and gender.

\section{Results}

For each of our dependent variables, we run three models: Model (1) is a baseline model where we include all explanations for trade opinion but exclude support for Trump; in Model (2) we add our core independent variable, support for Trump, in order to test our first hypothesis, the "Trump Effect;" Model (3) tests the second hypothesis by adding the interaction term between support for Trump and political knowledge. Table 1 includes all three models with attitudes toward import restrictions as the dependent variable, while Table 2 includes all three models with attitudes toward free trade agreements as the dependent variable.

\section{Attitudes toward Import Restrictions}

We first explore determinants of attitudes toward import restrictions. We purposefully coded opposing import limits as 1 and supporting import limits as 0 , so that a positive coefficient in Table 1 indicates a positive association between the independent variable and support for free trade. As one can see from Table 1 Model (1), before we consider support for Trump, partisanship has a negative and significant effect on the dependent variable. Because Republican is coded as a higher value in partisanship, a negative coefficient of partisanship means Republicans are more likely to support import limits, and Democrats are more likely to oppose import limits. This is consistent with Mutz's (2018) finding that Republicans were more negative about trade in recent years. Additionally, one's political knowledge and education levels both have a positive and significant effect, but nationalism has a negative and significant effect on the 
dependent variable. These results suggest that individuals with lower levels of education, lower levels of political knowledge, or stronger nationalist views are more negative about open trade.

Moving to Table 1 Model (2) in which we add support for Trump, we notice that Trump support has a negative and highly significant effect on the dependent variable. Intuitively, this result suggests that Trump supporters are more likely to support placing new limits on imports, and this finding verifies our first hypothesis. Interestingly, once we consider Trump support, the effect of partisanship becomes insignificant. In other words, even though on surface it seems like Republicans were more likely to hold anti-trade opinions during the 2016 Presidential election, once we take the "Trump effect" into consideration, the role of partisanship disappears; instead, it is Trump supporters who consistently held more anti-trade opinion. This finding verifies our speculation that the "Trump effect" on trade opinion goes beyond partisan lines. In a robustness test, we further split our sample by respondents' partisanship and see whether the Trump effect exists among Democrats and Independents.

In order to test our second hypothesis, we include an interaction term between political knowledge and support for Trump in Table 1 Model (3). The results show that both the interaction term and political knowledge have significant effects on the dependent variable. The interaction term makes straightforward interpretation of the coefficients challenging from the table alone, therefore, we graph a figure by using the Clarify addition to Stata 12.0 to intuitively display the conditional effect of political knowledge on support for Trump and supporting/opposing import restrictions (King, Tomz, \& Wittenberg, 2000). ${ }^{11}$ Below Figure 1 (a) displays the predicted effects of Trump support on "opposing import restrictions" among individuals with high and low levels of political knowledge. As one can see, the line for high levels of political knowledge has a much steeper slope compared to the line for low levels of 
political knowledge, indicating that the effect of Trump support on "opposing import restrictions" is larger among individuals with high levels of political knowledge. More specifically, among political knowledgeable citizens, the predicted probability for non-Trump supporters (when feeling thermometer of Trump=0) to oppose import restrictions was about $62 \%$, but for Trump supporters (when feeling thermometer of Trump=100) the rate quickly reduced down to $15 \%$, creating a difference of $47 \%$. However, among individuals with low levels of political knowledge, the difference in predicted probability of opposing import restrictions between non-Trump supporters (46\%) and supporters (18\%) is only 28 percentage points, a much smaller gap.

Figure 1(b) shows a similar pattern. Likewise, among politically knowledgeable citizens, the predicted probability for non-Trump supporters (when feeling thermometer of Trump $=0$ ) to support import restrictions is only 38\%, but for Trump supporters (when feeling thermometer of Trump $=100$ ) it is $85 \%$, for a difference of 47 percentage points. However, among individuals with low levels of political knowledge, the difference between non-Trump supporters (54\%) and supporters (82\%) is only 28 percentage points, a much smaller difference. Overall, Figure 1(a) and (b) both show strong support for our second hypothesis, in that the "Trump effect" is amplified among politically knowledgeable individuals. Model (3) still shows that partisanship does not have a significant effect on trade opinion, while nationalism, education and financial worry all still have similar effects on the dependent variable. Overall, these findings lend support for our two hypotheses and are consistent with previous studies. In the Supplemental Material, we compare the magnitude of the Trump effect with the effects of other variables, and the results show that the Trump effect is the largest compared to other variables.

\section{Attitudes toward Free Trade Agreements}


We now turn to Table 2 when we use attitudes toward free trade agreements as our dependent variable. Model (1) shows that partisanship, nationalism and union membership all have significant and negative effects, and education has a significant and positive effect on attitudes toward free trade agreements. These results suggest that Republicans, Union members, and those with nationalist views or lower education levels are more likely to oppose free trade agreements. Again, we find no support for the effects of skill levels or industry-level exposure to trade, consistent with findings from Table 1 and those from Mansfield and Mutz (2009).

Different from Table 1, we do not observe a significant effect of political knowledge or financial worry on attitudes toward free trade agreements.

Moving to Model (2) when we add Trump support, we find that Trump support again has a significant and negative effect on support for free trade, lending further support to our first hypothesis. Once including Trump support, we notice that the coefficients of both nationalism and party identification shrink and are no longer statistically significant, but education level and union membership still significantly impact attitudes toward free trade agreements. This suggests that in 2016, the "Trump effect" on trade opinion goes beyond partisan lines, and it is Trump's supporters that were more likely to hold negative views about free trade agreements, rather than a particular partisan or ideological group.

To test our second hypothesis, Model (3) includes an interaction term between Trump support and political knowledge. Again, in order to more intuitively interpret the conditional effect, we graph figures by using the Clarify addition to Stata 12.0 (King, Tomz, \& Wittenberg, 2000) and present the results in Figure 2. Figure 2(a) and 2(b) display the predicted probabilities for supporting and opposing free trade agreements, respectively, across support for Trump among individuals with high and low levels of political knowledge. In both figures, the lines 
representing high levels of political knowledge show a steeper curve, suggesting a larger effect of Trump support on attitudes toward free trade agreements. In Figure 2(a), we can see that as Trump support increases from 0 to 100 , the predicted probability of favoring free trade agreements decreased quickly from $59 \%$ to $19 \%$ among those who are politically knowledgeable. Yet, among individuals with low levels of political knowledge, the predicted probability of favoring free trade agreements stayed relatively the same, only changing from $47 \%$ to $30 \%$. This is because individuals with low levels of political knowledge are less likely to acquire or receive political information on trade issues, and even if they do, they are less able to analyze the message to accept/reject it based on their political predisposition.

Figure 2(b) shows a similar pattern. The predicted probability of opposing free trade agreements is the highest among Trump supporters with high levels of political knowledge. This is because (1) Trump supporters are more likely to hold anti-trade political predispositions, and (2) politically knowledgeable Trump supporters are more likely to acquire information on trade issues and also more able to accept protectionist rhetoric in forming their opinions as such rhetoric is consistent with their own predisposition. Overall, Figure 2 provides decent support for our second hypothesis. In the Supplemental Material, we compare the magnitude of the Trump effect with the effects of education (the only control variable that has a significant effect), and the results show that the magnitude of the Trump effect is comparable to that of education.

In sum, our empirical findings offer strong support for both of our hypotheses: supporters of Donald Trump are more likely to adopt a protectionist view of trade, and this effect varies based on individuals' ability to accept these messages based on their political knowledge. Additionally, we show that although there appears to be a partisan difference in trade opinions, the effect of partisanship disappears when we consider support for Trump. Objective measures of 
one's economic self-interest such as their skill level and the import-orientation of their sector do not have a significant effect on trade opinion. Our findings also suggest that education is a consistently important factor for individual opinions on trade, even after taking account of emotional factors based on nationalism and ethnocentrism, consistent with prior research which finds consistent effects of education (e.g. Kaltenthaler etl al, 2004). Nationalist views have a significant effect on Americans' trade opinion, although the effect of nationalism on attitudes toward free trade agreements falls out when considering Trump support. These findings are consistent with conclusions drawn by an important trade opinion study in Mansfield and Mutz (2009). Even though we did not find any evidence that ethnocentrism affects trade opinion, it is perhaps because trade opinion is centered around concerns of the declining status of the nation rather than a specific racial group.

\section{Robustness Checks}

\section{Using IV-2SLS to Address Endogeneity}

Even though our empirical analyses show strong support for both hypotheses, we find it imperative to address the problem of reverse causality, or endogeneity between support for Trump and trade opinion. Fordham and Kleinberg (2012), for example, claim that predicting support for trade based on related attitudes is inherently problematic in terms of determining the direction of causality. In our case, it is possible that individuals' trade attitudes are influenced by Trump's rhetoric; however, it is also possible that individuals choose to support Trump because of their existing anti-trade attitudes. In order to better test our hypothesis, we need to ensure the Trump effect on trade opinion is robust even when accounting for the possibility of reverse causality. To do this, we employ a two-stage least-squares model with instrumental variables (IV-2SLS) to address the endogeneity issue. By using instruments which are exogenous to the 
dependent variable and highly correlated with our independent variable, we can "purge" the endogenous component of the independent variable and assess whether its effect on our dependent variable still holds (Baum, Schaffer and Stillman 2007).

We are able to identify three instrumental variables from the 2016 ANES dataset which meet the required conditions: (1) respondents' opinion on whether the country needs a “strong, determined leader who will crush evil and take us back to our true path;” (2) respondents' opinion on whether Barack Obama is a Muslim; and (3) a feeling thermometer towards illegal immigrants. These instruments meet the requirements because: (1) they are related to support for Trump; (2) there is no direct theoretical causal connection between these three instruments and individuals' trade opinion. A more detailed description on how we choose these instruments and a full set of diagnosis tests are included in the Supplemental Materials. All the diagnosis tests show that our instruments meet all the requirements.

Turning to the results of the IV-2SLS models, in the first stage models, as shown in Table 3, we estimate Trump support as a function of the instrumental variables and the control variables in our original models. The predicted values of the first stage models, or fitted values, represent an instrumented measure of Trump support purged of the influence of trade attitudes. We then, in the second stage models, use the purged Trump support variable to predict two dependent variables: (1) attitudes toward import restrictions, (2) attitudes toward free trade agreements.

Results of the second stage models are presented in Table 4. In Table 4 Model (1), the coefficient for Trump Support $(b=-.008, \mathrm{SE}=.001)$ is still negative and statistically significant, suggesting that Trump support still has a significant positive effect on trade opinion even after we control for endogeneity. Likewise, the coefficient for Trump support in Model (2) $(b=-.009$, 
$\mathrm{SE}=.002)$ is still negative and statistically significant, also suggesting that Trump support still has the same effect on support for free trade agreement after accounting for endogeneity. Based on these results, we are confident that our empirical tests withstand the challenges of endogeneity and reverse causality.

\section{Differentiating Trump Effect from Partisan Effect}

In this paper, we argue that elite persuasion can have effects above and beyond that of partisanship, but we also understand that the effect of political elites and partisan effect can be hard to differentiate. For example, one may raise the concern that changes in trade attitudes among the highly politically knowledgeable Trump supporters are actually because of Republicans bringing their attitudes in line with the Republican presidential nominee. We conduct some additional analyses to further differentiate the Trump effect from partisan effect. We argue that if the above-mentioned concern is true, then the "Trump effect" on trade attitudes should be observed only among Republican copartisans, and not among Democrats or independents, as non-Republicans do not have the same party pressure to update their beliefs.

We would also observe that only the individuals most supportive of Trump exhibit this pattern of updating their beliefs, as opposed to individuals who are cold or lukewarm towards Trump. To test whether the effects of Trump support on trade opinion follow these patterns, we re-estimate Model (3) from Tables 1 and 2, this time splitting our sample by party identification (Independent, Democrats, and Republicans) and Trump support (0-50 vs 51-100).

The results show a different pattern as predicted by a partisan explanation. It appears that the impact of Trump support on trade attitudes is more salient among Democrats and independents, and the group of individuals who are cold or lukewarm toward Trump. In fact, we observe null effects for Trump support when we restrict the sample to Republicans only or to 
strong Trump supporters only. We have included these additional results in our Supplemental Materials. Taken together, these results suggest an opposite pattern of what we would expect if trade attitude changes were driven primarily by partisan motivated reasoning (i.e., Republicans being influenced by their party's nominee); therefore, we are confident that the Trump effect we observe is truly driven by Trump himself and it is beyond the partisan effect.

\section{Is the Trump Effect Repeatable?}

In order to make sure the "Trump effect" we observe in 2016 is not a single case, we provide additional evidence to show that the effect of elite rhetoric is enduring and repeatable.

Considering that an important reason behind the observed Trump effect is Trump's fierce attack against free trade, we needed to find another presidential candidate who did the same, and this itself was a difficult task, simply because Trump was the first major party presidential candidate to openly advocate U.S. foreign trade retrenchments. In recent history, we only found one third party presidential candidate, who similarly attacked free trade. In the 1992 presidential election, Ross Perot, the Reform Party presidential candidate famously said that a trade agreement like NAFTA will cause a "giant sucking sound" when jobs are lost to Mexico (Shalken 2019). He fiercely and openly attacked free trade and repeatedly said free trade was bad for American jobs. His message resonated with "workers, unions, environmentalists and people in manufacturing towns across the country, helping him earn 20 million votes or about $19 \%$ of the total" (Shalken 2019: 1). His attack on free trade was still remembered by many today. Based on our theory, Ross Perot should have a similar negative effect on public trade opinion. We employ the 1992 ANES data to test the proposition, and our results indeed show a strong and significant "Perot effect" on public trade opinion. The results are included in the Supplemental Materials. 
Additionally, we employ the Voter Study Group (VSG) 2017 survey data to test whether the Trump effect remained one year after the election. In this test, we use Americans' attitudes toward free trade as the dependent variable, and one's Trump favorability as the independent variable. We observe a similar effect: Trump favorability in 2017 was still a significant predictor of one's trade attitudes; those who favored Trump were still much more likely to oppose free trade in 2017. The results of this robustness test are also included in the Supplemental Materials. Taken together, these two tests show additional evidence that the influence of political elites' anti-free trade discourse on public trade opinion is repeatable and enduring.

\section{Conclusion}

The 2016 presidential election featuring Donald Trump's attack on open trade and the subsequent trade war with China has brought the issue of trade into the center stage of American politics. During his campaign and presidential debates in 2016, Trump persistently and fiercely attacked the US's trade deficits, its trade policies and accused other countries of taking advantage of the US in international trade. Various public opinion polls show that Americans' support for free trade fell sharply during 2016 (Jones 2017). This paper takes a first step to examine the previously overlooked effect of political elites on trade opinion.

By using the 2016 ANES data, we find that Trump supporters are significantly more likely to oppose free trade agreements and support imports restrictions. This relationship remains strong and significant even when we control for the possibility of endogeneity (i.e., individuals support Trump because of their trade opinion). Interestingly, when we consider Trump support, the effect of partisanship on trade opinion disappears. Our additional robustness check suggests that Trump effect on trade opinion was not merely a partisan effect, as the Trump effect was more salient among Democrats and Independents. Even though Mutz (2017) ascribed the change 
in trade opinion after 2016 to partisanship, our paper highlights the Trump effect and differentiates it from a pure partisan effect.

Our project also suggests that the effect of Trump support on trade opinion is conditioned by one's political knowledge. The effect of Trump support on trade opinion is larger among individuals with higher levels of political knowledge, and this is because knowledgeable individuals are more likely to acquire political information and more able to accept political messages consistent with their political predispositions. Conversely, individuals with low levels of political knowledge do not care about politics as much and as a result are not interested in acquiring political information related to complex issues like trade; they are also less likely to hold a strong or stable political predisposition, and far less able to analyze or absorb information from political elites based on their own political predisposition. Our research provides confirmation to Zaller's view that public opinion is heavily influenced by political elites and that political knowledge plays an important role in this process.

Findings from our paper also suggest a complex reality of presidential support in America today. Through his campaign messages, Donald Trump successfully tapped into many Americans' feelings of decline and marginalization in a globalized age and transformed that into support and even faith in him. It is often suggested that individuals with lower levels of education are more likely to be Trump supporters. However, our research shows that among his supporters, it is the more knowledgeable ones who are more likely to be influenced by Trump's views on important issues like trade. Knowledgeable Trump supporters share a few traits that make them the strongest base of Donald Trump: (1) they are sophisticated enough to hold stable political predispositions similar to Trump's views, (2) they are more interested in acquiring political messages from Trump and others on complex issues, and (3) they are more capable of 
analyzing these messages and accept information consistent with their existing predispositions. Because Trump's supporters have similar prejudices and political views with him, messages delivered by Trump that carry stereotypical frames will align with their predisposition and result in a higher chance for them to accept these messages and update their beliefs. While this is not exactly a calculus of economic costs and benefits, it is also not completely "irrational" behavior.

Although Americans' perceptions of free trade have declined in recent years, the Pew Research Center shows that Americans' support for free trade already rebounded from a historical low in 2017 (Jones 2017). The escalation of the trade war was perhaps the sobering moment for many Americans. When businesses witness lower demand of exported products and when consumers experience increased price of imported goods, they may start to "feel the pain" and shift back toward support for free trade.

Our study is not without limitations. Due to limitations of data availability, we did not directly test the effect of elite discourse/rhetoric on trade opinion. Experimental studies directly linking Trump's campaign messages on trade and changes in one's trade opinion could more accurately capture the causal mechanism between elite rhetoric and trade opinion. However, at the minimum, our study offers a critical perspective for understanding the nature of Americans' attitudes toward free trade in this current political environment. While it remains important to consider both economic circumstances and relevant symbolic attitudes in the study of trade opinion, we show that it is also critical to consider to what extent individuals' policy opinions are influenced by political elites, and how Americans can form their opinion following political elites instead of their own economic calculus of costs and benefits. 


\section{References}

Abramowitz, A. I. (1978). The impact of a presidential debate on voter rationality. American Journal of Political Science, 680-690.

Azari, J. R. (2016). How the News Media Helped to Nominate Trump. Political Communication, 33(4), 677-680. https://doi.org/10.1080/10584609.2016.1224417

Baker, A. (2003). Why is trade reform so popular in Latin America?: A consumption-based theory of trade policy preferences. World Politics, 55(3), 423-455.

Balistreri, E. J. (1997). The performance of the Heckscher-Ohlin-Vanek model in predicting endogenous policy forces at the individual level. Canadian Journal of Economics, $30(1), 1-17$.

Baum, C.F., Schaffer, M.E. \& Stillman, S.. (2007). 'Enhanced Routines for Instrumental Variables/Generalized Method of Moments Estimation and Testing.' Stata Journal 7 (4): 465-506.

Blum, R. M., \& Parker, C. S. (2019). Trump-Ing foreign affairs: Status threat and foreign policy preferences on the right. Perspectives on Politics, 17(3), 737-755.

Brock, W. A., \& Magee, S. P. (1978). The economics of special interest politics: The case of the tariff. The American Economic Review, 68(2), 246-250.

Broockman, D. E., \& Butler, D. M. (2017). The Causal Effects of Elite Position-Taking on Voter Attitudes: Field Experiments with Elite Communication. American Journal of Political Science, 61(1), 208-221.

Bullock, J. G. (2011). Elite influence on public opinion in an informed electorate. American Political Science Review, 496-515. 
Campbell, A., Converse, P.E., Miller, W.E., \& Stokes., D.E. 1960. The American Voter. University of Chicago Press.

Carsey, T. M., \& Layman, G.C. (2006). “Changing Sides or Changing Minds? Party Identification and Policy Preferences in the American Electorate." American Journal of Political Science 50(2): 464-77.

Clark, P. F. (2017). 2016 Presidential Election: The Pivotal Role of Pennsylvania and the Rustbelt. Labor Studies Journal, 42(3), 239-244.

Cohen, G. L. (2003). Party Over Policy: The Dominating Impact of Group Influence on Political Beliefs. Journal of Personality and Social Psychology, 85(5), 808-822.

Cohn, N., \& Miller, C. C. (2019, November 26). They Voted Democratic. Now They Support Trump. The New York Times. https://www.nytimes.com

Dancey, L., \& Goren, P. (2010). Party identification, issue attitudes, and the dynamics of political debate. American Journal of Political Science, 54(3), 686-699.

Diamond, Jeremy. (2016) Trump: 'We can't continue to allow China to rape our country' CNN. Retrieved from https://www.cnn.com/2016/05/01/politics/donald-trump-chinarape/index.html/

Dias, E., Edwards, H.S., \& Vick, K. (2016, December 7) Voices from Democratic Counties Where Trump Won Big. https://time.com

Dür, A., \& Schlipphak, B. (2020) Elite cueing and attitudes towards trade agreements: the case of TTIP. European Political Science Review, 1-17.

Fordham, B. O., \& Kleinberg, K. B. (2012). How can economic interests influence support for free trade?. International Organization, 66(2), 311-328. 
Fowler, A. (2020). Partisan Intoxication or Policy Voting?. Quarterly Journal of Political Science, 15(2), 141-179.

Gabel, M., \& Scheve, K. (2007). Estimating the effect of elite communications on public opinion using instrumental variables. American Journal of Political Science, 51(4), 1013-1028.

Gilens, M., \& Murakawa, N. (2002). Elite Cues and Political Decision Making. In Political Decision Making, Deliberation and Participation (6), 15-49.

Guisinger, A. (2017). American opinion on trade: Preferences without politics. Oxford University Press.

Gujarati, D. N. \& Porter, D. C. (2012). Basic Econometrics $\left(6^{\text {th }}\right.$ edition). New York: McGrawHill.

Hackworth, J. (2019). Manufacturing decline: How racism and the conservative movement crush the American Rust Belt. Columbia University Press.

Hays, J. C., Ehrlich, S. D., \& Peinhardt, C. (2005). Government spending and public support for trade in the OECD: An empirical test of the embedded liberalism thesis. International Organization, 59(2), 473-494.

Heckscher, E. ([1919]1949). The Effect of Foreign Trade on the Distribution of Income. Readings in the Theory of International Trade, 4. Blakiston Company.

Herrmann, Richard K., Philip E. Tetlock, and Matthew N. Diascro. 2001. "How Americans Think about Trade: Reconciling Conflicts among Money, Power, and Principles.” International Studies Quarterly 45 (2): 191.

Hiscox, Michael J. 2006. "Through a Glass and Darkly: Attitudes toward International Trade and the Curious Effects of Issue Framing.” International Organization 60 (3): 755. 
Irwin, D. A. (1998). Against the tide: An intellectual history of free trade. Princeton University Press.

Jacoby, W. G. (1988). The Impact of Party Identification on Issue Attitudes. American Journal of Political Science, 32(3), 643-661.

Jessee, S. A. (2010). Partisan bias, political information and spatial voting in the 2008 presidential election. The Journal of Politics, 72(2), 327-340.

Johnston, R. (2006). PARTY IDENTIFICATION: Unmoved Mover or Sum of Preferences? Annual Review of Political Science, 9(1), 329-351.

Jones, B. (2017). Support for free trade agreements rebounds modestly, but wide partisan differences remain. Pew Research Center, 25. Retrieved from https://www.pewresearch.org/fact-tank/2017/04/25/support-for-free-trade-agreementsrebounds-modestly-but-wide-partisan-differences-remain/

Kaltenthaler, Karl C., Ronald D. Gelleny, and Stephen J. Ceccoli. 2004. "Explaining Citizen Support for Trade Liberalization.” International Studies Quarterly 48 (4): 829.

King, G., Tomz, M., \& Wittenberg, J. (2000). Making the most of statistical analyses: Improving interpretation and presentation. American Journal of Political Science, 44(2), 341-355.

Knowles, E. D., \& Tropp, L. R. (2018). The racial and economic context of Trump support: Evidence for threat, identity, and contact effects in the 2016 Presidential Election. Social Psychological and Personality Science, 9(3), 275-284.

Kunda, Z. (1990). The case for motivated reasoning. Psychological bulletin, 108(3), 480.

Lenz, G. S. (2012). Follow the leader?: how voters respond to politicians' policies and performance. University of Chicago Press.

Lodge, M., \& Taber, C. S. (2013). The rationalizing voter. Cambridge University Press. 
Major, B., Blodorn, A., \& Major Blascovich, G. (2018). The threat of increasing diversity: Why many White Americans support Trump in the 2016 presidential election. Group Processes \& Intergroup Relations, 21(6), 931-940.

Mansfield, E. D., \& Mutz, D. C. (2009). Support for free trade: Self-interest, sociotropic politics, and out-group anxiety. International Organization, 63(3), 425-457.

Margalit, Y. (2012). Lost in globalization: International economic integration and the sources of popular discontent. International Studies Quarterly, 56(3), 484-500.

Mayda, A. M., \& Rodrik, D. (2005). Why are some people (and countries) more protectionist than others?. European Economic Review, 49(6), 1393-1430.

McQuarrie, M. (2017). The revolt of the Rust Belt: place and politics in the age of anger. The British Journal of Sociology, 68, S120-S152.

Medrano, Juan Díez and Michael Braun. 2012. “Uninformed Citizens and Support for Free Trade." Review of International Political Economy 19 (3): 448.

Minozzi, W., Neblo, M. A., Esterling, K. M., \& Lazer, D. M. (2015). Field experiment evidence of substantive, attributional, and behavioral persuasion by members of Congress in online town halls. Proceedings of the National Academy of Sciences, 112(13), 3937-3942.

Morgan, S. L., \& Winship, C. (2015). Counterfactuals and causal inference. Cambridge University Press.

Mutz, D. (2017). Changing party alignments in American attitudes toward trade: reflections on the past, implications for the future. In The Future of the Global Order Colloquium. Perry World House, Philadelphia, PA. Orientation in Fifteen Languages and Twenty Countries." Social Psychological and Personality Science (Vol. 4, No. 5, pp. 587-99). 
Mutz, D. C. (2018). Status threat, not economic hardship, explains the 2016 presidential vote. Proceedings of the National Academy of Sciences, 115(19), E4330-E4339.

Mutz, D. C., \& Kim, E. (2017). The Impact of In-group Favoritism on Trade Preferences. International Organization, 71(4), 827-850.

O'Rourke, K. H., Sinnott, R., Richardson, J. D., \& Rodrik, D. (2001). The determinants of individual trade policy preferences: International survey evidence [with comments and discussion]. In Brookings trade forum (pp. 157-206). Brookings Institution Press.

Rodrik, D. (1997). GLOBALIZATION, SOCIAL CONFLICT AND ECONOMIC GROWTH. Prebish Lecture presented at the UNCTAD, Geneva.

Rogers, S. (2020). Sobering up after" Partisan Intoxication or Policy Voting?". Quarterly Journal of Political Science, 15(2), 181-212.

Sargan, J. (1988). Testing for misspecification after estimation using instrumental variables. In John Denis Sargan, ed. E. Maasoumi, ed. Contributions to econometrics. (1). Cambridge: Cambridge University Press.

Scheve, K. F., \& Slaughter, M. J. (2001). What determines individual trade-policy preferences?. Journal of International Economics, 54(2), 267-292.

Schonfeld, B., \& Winter-Levy, S. (2019). Policy or Partisanship in the United Kingdom? QuasiExperimental Evidence from Brexit. Journal of Politics, Forthcoming.

Stock, J. H., and M. Yogo. (2005). Testing for weak instruments in linear IV regression. In D. W. K. Andrews and J. H. Stock, ed. Identification and Inference for Econometric Models: Essays in Honor of Thomas Rothenberg. 80-108. Cambridge: Cambridge University Press. 
Stolper, W. F., \& Samuelson, P. A. (1941). Protection and real wages. The Review of Economic Studies, 9(1), 58-73.

Tomz, M., \& Van Houweling, R. P. (2008). Candidate positioning and voter choice. American Political Science Review, 303-318.

Wells, C., Shah, D. V., Pevehouse, J. C., Yang, J., Pelled, A., Boehm, F., ... Schmidt, J. L. (2016). How Trump Drove Coverage to the Nomination: Hybrid Media Campaigning. Political Communication, 33(4), 669-676.

Winslett, Gary. 2016. "Public Opinion Distribution and Party Competition in US Trade Policy." World Economy 39 (8): 1128-45.

Wooldridge, J. M. (2009). Introductory Econometrics: a modern approach. 4th. CENGAGE Learning, Canada.

Zaller, J. R. (1992). The nature and origins of mass opinion. Cambridge university press. 


\section{Endnotes}

[1] Below are a few examples of Trump's rhetoric when attacking trade. "We as a nation lost $\$ 817$ billion dollars on trade. That is ridiculous and it is unacceptable." "I have visited the cities and towns across America and seen the devastation caused by the trade policies of Bill and Hillary Clinton...NAFTA is the worst trade deal maybe ever signed anywhere but certainly ever signed in this country." "You go to New England, Ohio, Pennsylvania, you go anywhere you want, and you will see devastation where manufacturing is down 30,40 , sometimes 50 percent."

[2] Below are a few examples of Trump's attacks on America's trade partners: "We're not making things anymore, relatively speaking. Our product is pouring in from China, pouring in from Vietnam, pouring in from all over the world. We have people that are political hacks negotiating our trade deals." "People have no idea how badly our country has been treated by other countries. They've destroyed the steel industry, they've destroyed the aluminum industry." "You take a look at what's happening to steel and the cost of steel and China dumping vast amounts of steel all over the United States, which essentially is killing our steelworkers and our steel companies."

[3] Besides these hardcore Trump supporters who share similar political views with him, one may argue that there are other types of Trump supporters such as reluctant Republicans supporting the nominee of their political party and individuals who dislike Hillary Clinton and as a result supported Trump. These unwilling Trump supporters only comprise a very small portion of the "big tent" of Trump supporters, as our data show. For example, reluctant Republican supporters of Trump (i.e., Republicans who voted for Trump but had a lower than average feeling thermometer score of Trump) only comprised $4.1 \%$ of all Trump supporters. Individuals supporting Trump only because they dislike Hillary Clinton (i.e., individuals who voted for Trump but had a lower than average feeling thermometer score for Clinton and Trump) only comprised $6.0 \%$ of all Trump supporters. Therefore, in this paper we focus our attention on the majority of the "big tent" of Trump supporters, or the core groups of Trump supporters, who are either economically left behind, or felt a status threat. These two groups may or may not support Trump himself, but they both tend to share similar anti-trade and anti-openness views with Trump.

[4] Since the seminal work by Campbell et al. (1960), a rich body of previous research has studied the importance of partisanship on public opinion formation. Individuals' party identification is often considered as a "prime mover" of their issue attitudes. Individuals receive cues from party leaders, and the cues will then play an influential role in the development of their policy positions (e.g. Jacoby 1988; Gilens and Murakawa 2002; Cohen 2003; Johnston 2006). The classic "Michigan model" even claims that party identification is the "unmoved mover" of political issue attitudes (e.g. Campbell et al., 1960). Political psychologists have identified the prevalence of motivated reasoning, where individuals, on a cognitive level, tend to selectively receive and interpret information to support certain conclusions that match their party identification (Kunda 1990; Taber and Lodge 2013). 
[5] Because of our inclusion of ethnocentrism, we estimate our main statistical models by only including non-Hispanic white respondents, but present statistical results when considering all respondents in our Supplemental Material. The results remain the same.

[6] Responses of this question include seven categories: "oppose a great deal" (6.9\%), "oppose moderately" (9.46\%) "oppose a little" (3.84\%) "neither favor nor oppose" $(40.31 \%)$, "favor a little" (6.82\%) "favor moderately" (22.84\%) and "favor a great deal" $(9.85 \%)$. Because a significant plurality of individuals answered this question neutrally, we combined the three "oppose" responses into one, and the three "favor" responses into one category, in order to make the three categories more balanced. We also ran the same models by using the original sevencategory variable, and the results remain the same. These results are included in Supplemental Material.

[7] We first collect data on wages and salaries per full-time equivalent employee by industry from the Bureau of Economic Analysis (BEA), then merge these income data with ANES using the NAICS occupation codes. Because 1,595 respondents reported their employment status as unemployed, retired, permanently disabled, homemaker or student, we could only match industry-level average income and import orientation data for the rest of the respondents who reported a valid industry of occupation. This limitation resulted in a much smaller sample size of our models. To remedy this, we also matched industry-level data based on respondents' most recent occupation if they are unemployed, retired, permanently disabled, homemakers or students. We ran the same models with the expanded sample, and the main results stay the same. These additional results and their interpretation are included in the Supplemental Material.

[8] Using information from the Bureau of Economic Analysis and the US Census Bureau NAICS Trade Database, we calculate export and import orientation for each industry. We then match each individual with an industry using their self-reported occupation and the NAICS codes. For cases in which BEA Industry GDP data was an aggregate of multiple NAICS codes, the total import/export amounts for those sectors were added together, and divided by the combined GDP.

[9] These five questions include: (1) how seeing the American flag flying makes the respondent feel, (2) how important is American identity to the respondent, (3) whether the world would be better if it was more like the USA, (4) if being American means following American customs, and (5) whether being American means being born in the USA. We generate a new variable nationalism and rescale it to $0-1$. The retained principal component factor has an eigenvalue of 2.34 and an alpha statistic of .71.

[10] The retained principal component factor has an eigenvalue of 2.36 and an alpha statistic of .86 .

[11] For display purposes we use the $75^{\text {th }}$ percentile value of political knowledge as an example of knowledgeable individuals, and the $25^{\text {th }}$ percentile value of political knowledge as an example of individuals holding low levels of political knowledge. 
Table 1. Trump Support, Political Knowledge and Opposing Import Restrictions

\begin{tabular}{|c|c|c|c|c|c|c|}
\hline & \multicolumn{2}{|c|}{ Model (1) } & \multicolumn{2}{|c|}{ Model (2) } & \multicolumn{2}{|c|}{ Model (3) } \\
\hline & $\begin{array}{l}\text { Coefficient } \\
\text { (b) }\end{array}$ & $\begin{array}{l}\text { Standard } \\
\text { Error }\end{array}$ & $\begin{array}{l}\text { Coefficient } \\
\text { (b) }\end{array}$ & $\begin{array}{l}\text { Standard } \\
\text { Error }\end{array}$ & $\begin{array}{l}\text { Coefficient } \\
\text { (b) }\end{array}$ & $\begin{array}{c}\text { Standard } \\
\text { Error }\end{array}$ \\
\hline Support for Trump & & & $-0.018^{* * *}$ & $(0.003)$ & -0.001 & $(0.006)$ \\
\hline Political Knowledge & $0.103^{* *}$ & $(0.037)$ & $0.091^{*}$ & $(0.038)$ & $0.222^{* * *}$ & $(0.058)$ \\
\hline Support for Trump $\times$ Knowledge & & & & & $-0.003^{* *}$ & $(0.001)$ \\
\hline Skill Level & -0.001 & $(0.002)$ & -0.001 & $(0.002)$ & -0.002 & $(0.002)$ \\
\hline Import Orientation & 0.014 & $(0.011)$ & 0.016 & $(0.011)$ & 0.015 & $(0.011)$ \\
\hline Financial Worry & $-0.245^{* * *}$ & $(0.062)$ & $-0.238^{* * *}$ & $(0.063)$ & $-0.237^{* * *}$ & $(0.063)$ \\
\hline Nationalism & $-2.239^{* * *}$ & $(0.407)$ & $-1.373^{* *}$ & $(0.433)$ & $-1.320^{* *}$ & $(0.438)$ \\
\hline Ethnocentrism & -0.051 & $(0.072)$ & -0.071 & $(0.073)$ & -0.069 & $(0.074)$ \\
\hline Age & -0.009 & $(0.005)$ & -0.008 & $(0.005)$ & -0.008 & $(0.005)$ \\
\hline Household income & -0.000 & $(0.011)$ & -0.003 & $(0.011)$ & -0.003 & $(0.011)$ \\
\hline Party ID & $-0.189^{* * *}$ & $(0.034)$ & -0.031 & $(0.044)$ & -0.010 & $(0.044)$ \\
\hline Education & $0.131^{* * *}$ & $(0.038)$ & $0.113^{* *}$ & $(0.039)$ & $0.108^{* *}$ & $(0.039)$ \\
\hline Union Membership & -0.376 & $(0.213)$ & -0.340 & $(0.216)$ & -0.332 & $(0.218)$ \\
\hline Gender & -0.171 & $(0.140)$ & -0.229 & $(0.144)$ & -0.200 & $(0.144)$ \\
\hline$N$ & \multicolumn{2}{|c|}{1195} & \multicolumn{2}{|c|}{1191} & \multicolumn{2}{|c|}{1191} \\
\hline
\end{tabular}

Note: $\quad * \mathrm{p}<0.05, * * \mathrm{p}<0.01, * * * \mathrm{p}<0.001$

Coefficients and standard errors rounded to 3 decimal places. Constant estimates omitted. 
Table 2. Trump Supporters, Political Knowledge and Support for Free Trade Agreements

\begin{tabular}{|c|c|c|c|c|c|c|}
\hline & \multicolumn{2}{|c|}{ Model (1) } & \multicolumn{2}{|c|}{ Model (2) } & \multicolumn{2}{|c|}{ Model (3) } \\
\hline & $\begin{array}{l}\text { Coefficient } \\
\text { (b) }\end{array}$ & $\begin{array}{l}\text { Standard } \\
\text { Error }\end{array}$ & $\begin{array}{l}\text { Coefficient } \\
\text { (b) }\end{array}$ & $\begin{array}{l}\text { Standard } \\
\text { Error }\end{array}$ & $\begin{array}{l}\text { Coefficient } \\
\text { (b) }\end{array}$ & $\begin{array}{l}\text { Standard } \\
\text { Error }\end{array}$ \\
\hline Support for Trump & & & $-0.013^{* * *}$ & $(0.002)$ & -0.004 & $(0.004)$ \\
\hline Political Knowledge & 0.004 & $(0.027)$ & -0.009 & $(0.027)$ & 0.078 & $(0.044)$ \\
\hline Support for Trump $\times$ Knowledge & & & & & $-0.002^{*}$ & $(0.001)$ \\
\hline Skill Level & 0.000 & $(0.000)$ & 0.000 & $(0.000)$ & 0.000 & $(0.000)$ \\
\hline Import Orientation & 0.010 & $(0.008)$ & 0.011 & $(0.008)$ & 0.011 & $(0.008)$ \\
\hline Financial Worry & -0.061 & $(0.045)$ & -0.049 & $(0.045)$ & -0.046 & $(0.045)$ \\
\hline Nationalism & $-0.904^{* *}$ & $(0.310)$ & -0.187 & $(0.333)$ & -0.150 & $(0.334)$ \\
\hline Ethnocentrism & 0.060 & $(0.054)$ & 0.044 & $(0.054)$ & 0.050 & $(0.054)$ \\
\hline Age & 0.005 & $(0.004)$ & 0.005 & $(0.004)$ & 0.005 & $(0.004$ \\
\hline Household income & 0.008 & $(0.008)$ & 0.007 & $(0.008)$ & 0.007 & $(0.008)$ \\
\hline Party ID & $-0.099^{* * *}$ & $(0.026)$ & 0.009 & $(0.032)$ & 0.022 & $(0.032)$ \\
\hline Education & $0.148^{* * *}$ & $(0.027)$ & $0.132^{* * * *}$ & $(0.027)$ & $0.129^{* * *}$ & $(0.028)$ \\
\hline Union Membership & $-0.319^{*}$ & $(0.158)$ & $-0.318^{*}$ & $(0.159)$ & -0.301 & $(0.160)$ \\
\hline Gender & -0.105 & $(0.102)$ & -0.161 & $(0.103)$ & -0.144 & $(0.103)$ \\
\hline$N$ & \multicolumn{2}{|c|}{1539} & \multicolumn{2}{|c|}{1534} & \multicolumn{2}{|c|}{1534} \\
\hline
\end{tabular}

Note: $\quad * \mathrm{p}<0.05, * * \mathrm{p}<0.01, * * * \mathrm{p}<0.001$

Coefficients and standard errors rounded to 3 decimal places. Constant estimates omitted. 
Table 3: First Stage Models of the IV-2SLS Model

\begin{tabular}{|c|c|c|c|c|}
\hline & \multicolumn{4}{|c|}{ Dependent Variable: Support for Donald Trump } \\
\hline & \multicolumn{2}{|c|}{$\begin{array}{l}\text { Model (1) } \\
\text { First Stage OLS Model } \\
\left(2^{\text {nd }} \text { Stage DV: imports }\right)\end{array}$} & \multicolumn{2}{|c|}{$\begin{array}{c}\text { Model (2) } \\
\text { First Stage OLS Model } \\
\left(2^{\text {nd }} \text { Stage DV: free trade }\right)\end{array}$} \\
\hline Variable & $\begin{array}{l}\text { Coefficient } \\
\text { (b) }\end{array}$ & $\begin{array}{r}\text { Standard } \\
\text { Error (se) }\end{array}$ & $\begin{array}{l}\text { Coefficient } \\
\text { (b) }\end{array}$ & $\begin{array}{r}\text { Standard } \\
\text { Error (se) }\end{array}$ \\
\hline \multicolumn{5}{|l|}{ Instruments } \\
\hline Belief Obama is Muslim & $2.649^{* * *}$ & $(0.257)$ & $2.596^{* * *}$ & $(0.227)$ \\
\hline $\begin{array}{l}\text { Necessity of strong } \\
\text { leader }\end{array}$ & $4.677^{* * *}$ & $(0.595)$ & $4.946^{* * *}$ & $(0.527)$ \\
\hline Illegal Immigrant Feeling & $-0.158^{* * *}$ & $(0.030)$ & $-0.148^{* * *}$ & $(0.027)$ \\
\hline Political Knowledge & 0.363 & $(0.339)$ & 0.109 & $(0.300)$ \\
\hline $\begin{array}{l}\text { Skill Level (avg. } \\
\text { income) }\end{array}$ & 0.000 & $(0.000)$ & 0.000 & $(0.000)$ \\
\hline Import Orientation & 0.106 & $(0.100)$ & 0.052 & $(0.086)$ \\
\hline Financial Worry & 0.603 & $(0.548)$ & 0.277 & $(0.489)$ \\
\hline Nationalism & $20.611^{* * *}$ & $(4.332)$ & $24.200^{* * *}$ & $(3.784)$ \\
\hline Ethnocentrism & 0.834 & $(0.701)$ & 0.382 & $(0.617)$ \\
\hline Age & 0.017 & $(0.044)$ & 0.035 & $(0.039)$ \\
\hline Household income & -0.095 & $(0.096)$ & -0.073 & $(0.085)$ \\
\hline Party ID & $6.265^{* * *}$ & $(0.354)$ & $5.895^{* * *}$ & $(0.314)$ \\
\hline Education & -0.375 & $(0.349)$ & -0.387 & $(0.304)$ \\
\hline Union Membership & 3.138 & (1.916) & 2.271 & $(1.720)$ \\
\hline Gender & $-4.360^{* * *}$ & (1.274) & $-5.155^{* * *}$ & $(1.116)$ \\
\hline$N$ & 1163 & & 1485 & \\
\hline
\end{tabular}

Note: $\quad * \mathrm{p}<0.05, * * \mathrm{p}<0.01, * * * \mathrm{p}<0.001$

Coefficients and standard errors rounded to 3 decimal places. Constant estimates omitted. 
Table 4: Second Stage Models of the IV-2SLS Model

\begin{tabular}{lcccc}
\hline & \multicolumn{3}{c}{ Second Stage Dependent Variables } \\
& \multicolumn{2}{c}{$\begin{array}{c}\text { Model (1) } \\
\text { Attitudes toward import } \\
\text { restrictions }\end{array}$} & $\begin{array}{c}\text { Model (2) } \\
\text { Attitudes toward free trade } \\
\text { agreements }\end{array}$ \\
\hline Variable & $\begin{array}{c}\text { Coefficient } \\
(\mathrm{b})\end{array}$ & $\begin{array}{c}\text { Standard Error } \\
\text { (se) }\end{array}$ & $\begin{array}{c}\text { Coefficient } \\
(\mathrm{b})\end{array}$ & $\begin{array}{c}\text { Standard } \\
\text { Error (se) }\end{array}$ \\
\hline Instrumented IV & & & & \\
Support for Donald Trump & $-0.008^{* * *}$ & $(0.001)$ & $-0.009^{* * *}$ & $(0.002)$ \\
\hline Political Knowledge & $0.015^{*}$ & $(0.007)$ & -0.008 & $(0.010)$ \\
Skill Level (avg. income) & -0.000 & $(0.000)$ & 0.000 & $(0.000)$ \\
Import Orientation & 0.004 & $(0.002)$ & 0.005 & $(0.003)$ \\
Financial Worry & $-0.040^{* * *}$ & $(0.012)$ & -0.023 & $(0.017)$ \\
Nationalism & -0.058 & $(0.108)$ & 0.131 & $(0.155)$ \\
Ethnocentrism & -0.017 & $(0.014)$ & 0.013 & $(0.020)$ \\
Age & -0.001 & $(0.001)$ & 0.002 & $(0.001)$ \\
Household income & -0.000 & $(0.002)$ & 0.001 & $(0.003)$ \\
Party ID & $0.033^{*}$ & $(0.014)$ & $0.040^{*}$ & $(0.019)$ \\
Education & $0.016^{*}$ & $(0.008)$ & $0.050^{* * *}$ & $(0.011)$ \\
Union Membership & -0.047 & $(0.042)$ & $-0.127^{*}$ & $(0.059)$ \\
Gender & -0.053 & $(0.028)$ & -0.050 & $(0.039)$ \\
\hline$N$ & 1163 & & 1485 & \\
\hline & & & &
\end{tabular}

Note: $\quad * \mathrm{p}<0.05, * * \mathrm{p}<0.01, * * * \mathrm{p}<0.001$

Coefficients and standard errors rounded to 3 decimal places.

Constant estimates omitted. 
Figure 1. Trump Support, Political Knowledge and Attitudes toward Import Restrictions, based on Table 1 Model (3)

(a). Predicted Probability of Opposing Import Restrictions for High-/Low-levels of Political knowledge

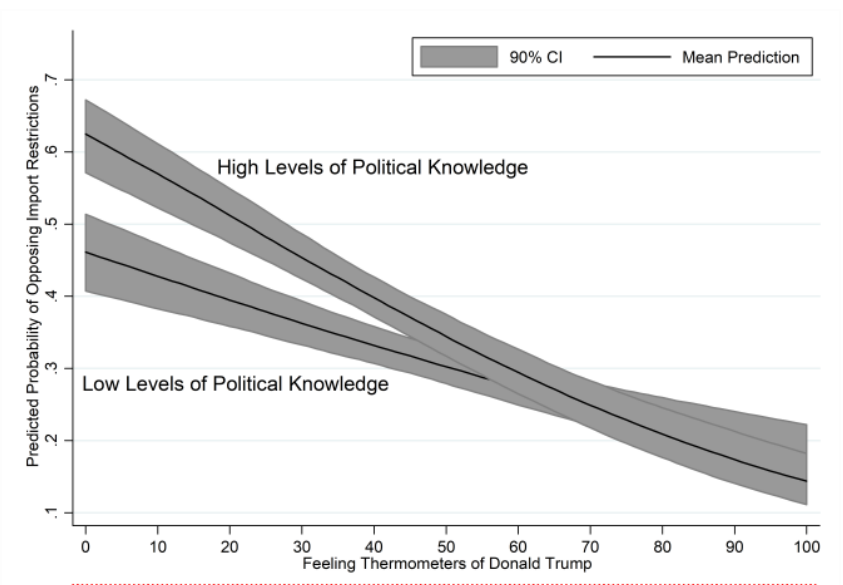

(b). Predicted Probability of Supporting Import Restrictions for High-/Low-levels of Political knowledge

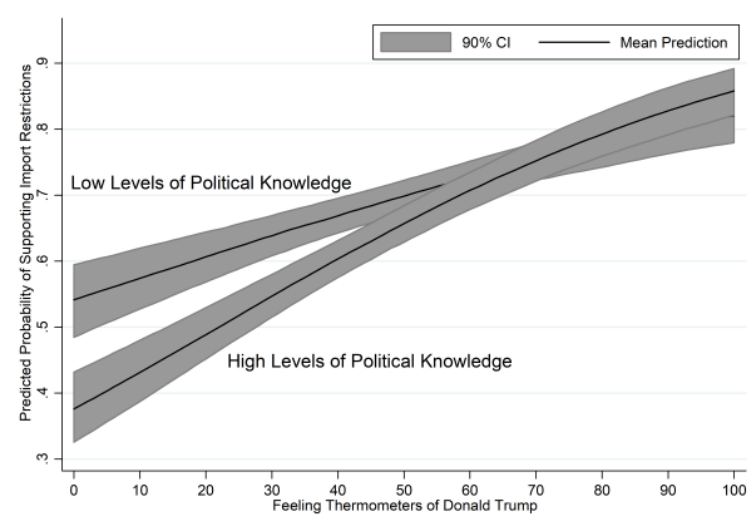

Figure 2. Trump Support, Political Knowledge and Attitudes toward Free Trade Agreements, based on

\section{Table 2 Model (3)}

(a) Favoring Free Trade Agreements among High-/Low-levels of Political Knowledge (b) Opposing Free Trade Agreements among High-/Low-levels of Political Knowledge
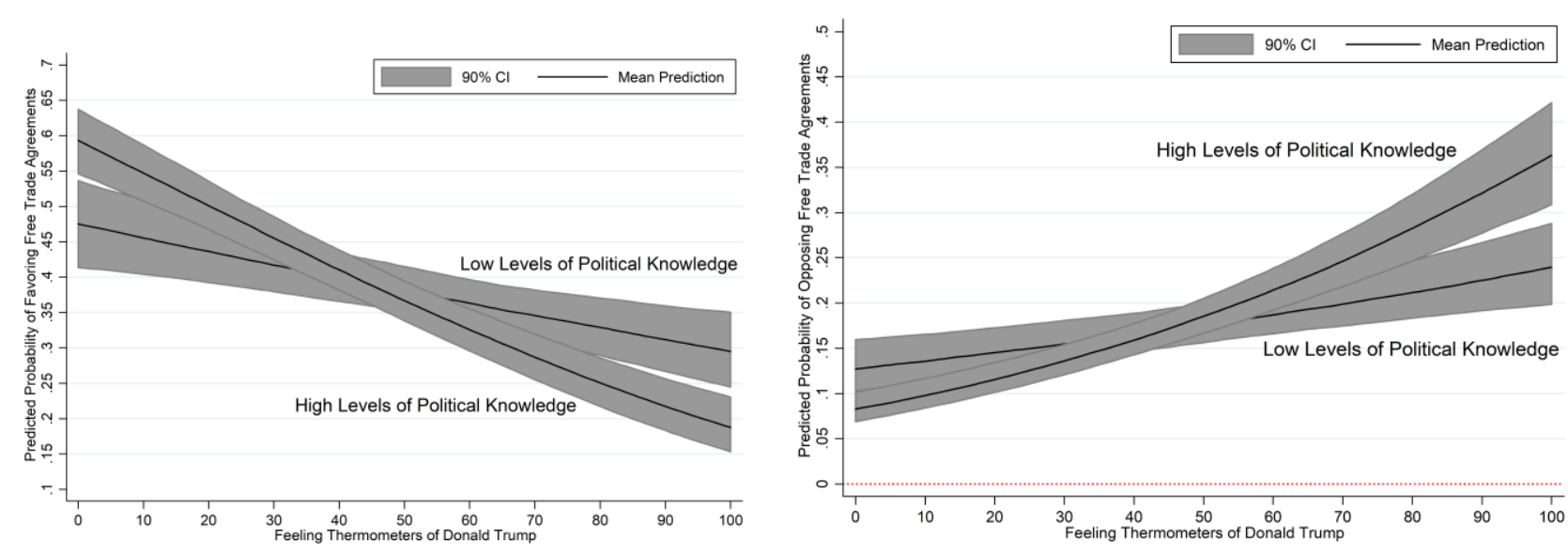